\title{
New concrete: Medium strength self- compacting concrete in colombia- invention patent (march 2019)
}

\author{
Nuevo hormigón: Hormigón autocompactable de resistencia media en colombia- \\ patente de invención (marzo 2019)
}

\author{
C. J. De-La-Cruz-Morales iD
}

\begin{abstract}
In civil construction, the need to seek greater durability in structures with a denser and more compact material, resistant to the attack of the environment and that demands a lower cost of maintenance and protection has promoted the development of Self Compacting Concrete (SCC) in the world. The results obtained with the use of SCC have been convincing for its use ratifying them as a new alternative that generates security, efficiency, speed, with ostensible improvements in the work environment and providing a significant economy in different ways, in the construction process. Hence the civil construction in Colombia requires the implementation of new efficient and sustainable technologies being the Medium-Low Resistance SCCs (SCC-MR) strength between $30 \mathrm{MPa}-45 \mathrm{MPa})$ the first tool that guarantees a fluid concrete no problems of segregation or exudation in fresh condition. These properties are determined in the laboratory and in situ. This material in Colombia, has been developed in the Laboratory of Structures of the Faculty of Mines of the National University of Colombia- Medellin following the methodology proposed for HAC-RMs, with excellent results, as presented in this Article, for the firm ACCIONA of Spain, Expo-Camacol in Colombia, among others and whose conclusions allowed to patent for the Superintendence of Industry and Commerce, a new alternative of concrete in the world.
\end{abstract}

Index Terms - self-compacting; exudation; fluidity; concrete; resistance; segregation.

Resumen-En la construcción civil, la necesidad de buscar mayor durabilidad en las estructuras, con un material más denso y compacto, resistente al ataque del medio ambiente y que demande un menor costo de mantenimiento y protección; ha promovido el desarrollo del Hormigón Autocompactable (HAC) en el mundo. Los resultados obtenidos con el uso del HAC, han sido convincentes para el empleo del mismo; ratificándolos como una nueva alternativa que genera seguridad, eficiencia, rapidez, con mejoras ostensibles en el ambiente de trabajo y proporcionando una economía significativa de diferentes formas, en el proceso constructivo. De ahí que, en Colombia, la construcción civil exija la implementación de nuevas tecnologías

This manuscript was sent on April 24, 2019 and accepted on February 20, 2020. Submission date for first revision of the article: February 18, 2019. "This work was supported by the Faculty of Mines of the National University of Colombia-Medellin Campus, under Resolution No. 69396."

C. J. Author, she is at the National University of Colombia of the Faculty of Mines- Campus Medellin, of the Civil Engineering Department. In Exclusive Dedication with Tenure of Position. E-mail: cjcruz @ unal.edu.co. eficientes y sostenibles; siendo los HACs de Resistencia MediaBaja (HAC-RM, entre $30 \mathrm{MPa}-45 \mathrm{MPa}$ ), la primera herramienta que garantiza un hormigón fluido (H.F); sin problemas de separación (segregación) o exudación en estado fresco. Dichas propiedades son determinadas en el laboratorio y en obra. Este material en Colombia, se ha desarrollado en el Laboratorio de Estructuras (LABEST) de la Facultad de Minas de la Universidad Nacional de Colombia- Sede Medellín, siguiendo la metodología propuesta para los HAC-RMs, con excelentes resultados, como se presentan en este artículo, para la firma ACCIONA de España, Expo-Camacol en Colombia, entre otros y cuyas conclusiones permitieron patentar por la Superintendencia de Industria y Comercio, una nueva alternativa de hormigón en el mundo.

Palabras claves---autocompactable; exudación; fluidez;hormigón; resistencia, segregación

\section{INTRODUCTION}

$\mathrm{A}$ MONG the most outstanding characteristics of Self Compacting Concrete (SCC), is its high fluidity and stability; in addition, it is compacted by the effect of gravity (zero (0) vibration), without any external compaction. It flows until leveling without presenting segregation of its components, nor blockage of the material when passing through the reinforcement in the formwork. The need to provide greater durability in the structures and therefore a denser and more compact material, with greater resistance to the attack of the environment, and in turn, which requires a lower cost of maintenance and protection, strength resistance between $30 \mathrm{MPa}$ and $45 \mathrm{MPa}$, has promoted the development of Medium Strength Self-Compacting Concrete (SCC-MR) in the world [1]. The SCC-MR, increases the performance and effectiveness in the production phase, facilitates the transport of fresh concrete, optimizes the filling of the form, reduces noise during the placement process and facilitates the processes of systematization in prefabrication, among others. The results obtained with the use of SCC in the world, have produced convincing results for its use, evidencing that it is an alternative that generates security, efficiency, speed and better work environment, providing a significant economy in different ways, within the constructive process.

The SCC-MR differs from conventional concrete (HC) and fluid concrete (HF) mainly for its properties in its fresh state 
which are determined in the laboratory and on site by means of a series of tests designed for such purposes whose results allow to quantitatively and qualitatively characterize SCC [1], [2], [3]. Therefore, we want to make known the new concrete alternative that is applied in the world, for the design and manufacture of SCC-MR and present in a simplified and effective way, the development and performance of SCCs-MR in Colombia, with the proper characterization of locally available materials. Hence, the National University of Colombia, having the patented SCC-MR (Resolution No. 69396-2018), offers a new technology of study and application, which involves one of the most important global trends, in terms of construction civil is concerned.

The SCCs-MR allow to contribute to the academic formation of the future civil engineers in the implementation of the new materials in the construction and to facilitate by means of the appropriation of an efficient methodology, the modernization of spaces of academic and professional formation, with the last ones experimental trends in the world [1], [2], [3]. It is worth noting that the SCC-MR in Colombia has been developed in the Laboratory of Structures (LABEST) of the Faculty of Mines of the National University of Colombia- Medellin Campus, with excellent results for the firm ACCIONA of Spain, Expo -Camacol in Colombia among others.

\section{Generalities}

In general fluency is one of the most important characteristics of SCC and therefore of SCC-MR [1], it must be taken into account that the stability or resistance to segregation is governed by the viscosity and cohesion of the mixture that transfer it to the composition of the concrete the

TABLE I

MAIN CHARACTERISTICS OF HV, HF AND SCC [1]

\begin{tabular}{|c|c|c|c|}
\hline Characteristics & HV & $\mathrm{HF}$ & SCC \\
\hline Employment & $\begin{array}{l}\mathrm{HC} \\
\text { Generalized } \\
\text { use }\end{array}$ & $\begin{array}{l}\text { Very Used, } \\
70 \text { s y } 80 \text { s }\end{array}$ & Decade of the $90 \mathrm{~s}$ \\
\hline Vibration & Intense & Lightweight & Not necesary \\
\hline $\begin{array}{l}\text { Consistency } \\
\text { and test method }\end{array}$ & $\begin{array}{l}\text { Plastic. } \\
\text { Cone of } \\
\text { AAbrams }\end{array}$ & $\begin{array}{l}\text { Cone de Abrams } \\
\text { (EHE, allows to } \\
\text { exceed then } \\
15 \mathrm{~cm} \text { with } \\
\text { additives sp) }\end{array}$ & $\begin{array}{l}\text { Characterization } \\
\text { SCCs. Filling } \\
\text { capacity } \\
\text { Resistance to } \\
\text { segregation. } \\
\text { Passage capacity }\end{array}$ \\
\hline Previous Test & Mechanics & $\begin{array}{l}\text { Mechanics and } \\
\text { simple } \\
\text { rheological } \\
\text { mechanics } \\
\text { (segregation and } \\
\text { exudation) }\end{array}$ & $\begin{array}{l}\text { Mechanical and } \\
\text { rheological, } \\
\text { fluidity, } \\
\text { segregation, } \\
\text { exudation, filling } \\
\text { capacity and } \\
\text { blockage }\end{array}$ \\
\hline $\begin{array}{l}\text { Influence of the } \\
\text { implementation } \\
\text { in the quality }\end{array}$ & High & Medium & Low \\
\hline
\end{tabular}

necessary homogeneity during transportation placement and commissioning. And this is how these properties are affected in concrete by factors such as the components type of mixture placement (pumping) and type of vibration [3]. The concrete flow evaluation is one of the most useful tools for its characterization in the fresh state. Hence determining the rheology of the material in the production of concretes one can determine the plasticity and the form of flow within the formwork. To get an idea of the difference between a vibrated concrete (HV) and HF and SCC (SCC-MR), Table I summarizes the characteristics of use, consistency, vibration, testing and influence of the work on the quality of these concretes [1].

\section{EXPERIMENTAL DETAILS}

The increasing use of SCC in the world and the need to have criteria for the optimization in the design of mixtures, require various techniques and / or tests to rationalize the selection of concrete components and their relative proportions.

Within this line of work one of the outstanding aspects is the study of the best combinations between the chemical additives and the cementing material (cement + additions). In the manufacture of a SCC and SCC-MR, the same materials as for $\mathrm{HC}$ are used in its basic composition in addition to the latest generation superplasticizer ( $\mathrm{sp}$ ) additive; where cement and aggregates do not have to meet specific requirements in addition to those required for a good quality HC [1], [3], [4], [5]. The components to be considered in the manufacture of a SCC-MR are water (W), cement $(\mathrm{C})$, aggregates, fine material (Filler, Sand $0 \mathrm{~mm}$ to $2 \mathrm{~mm}$ ), superplasticizers (sp) and viscosity modifying agents (AMVs) [1], [6], [7].

The SCCs-MR have been obtained only with the use of sps additives and without the use of additions [1], [7], [8]. The methodology used for the dosing of Colombian SCC-MR is described below [1], [3], [8]:

1) With locally available components and using the Marsh Cone the dose of the sp additive is determined in the paste and in the mortar with a $\mathrm{W} / \mathrm{C}$ ratio between 0.30 and 0.60 .

2) With the Mini-Slump test the $\mathrm{W} / \mathrm{C}$ ratio is set considering a paste of high fluidity and moderate cohesion.

3) Separately, the sand / gravel ratio is obtained corresponding to the dry combination of these components, which gives rise to the minimum content of voids. With this sand / gravel ratio concretes are manufactured with different volumes of paste or mortar (sp and fine / cement ratio initially determined).

4) The mixture is selected which with the minimum content of paste or mortar meets the requirements of self-compaction and resistance determined by several tests on fresh concrete.

In the Laboratory of Structures of the Faculty of MinesNational University of Colombia (LABEST), the tests of Slump, V Funnel and J Ring of Bars or Extension with Ring were chosen for the characterization in fresh state of the SCC-MR; establishing the following design criteria [1], [8]:

5) A Flow or Spread Extension of 65 to $75 \mathrm{~cm}$, for a T50 of 2 $\mathrm{s}$ to $8 \mathrm{~s}$.

6) Download time of the SCC-RM, in the V-Funnel test, from $2 \mathrm{~s}$ to $5 \mathrm{~s}$. 
7) One $\mathrm{CB}$ for the trial of the Ring of Bars or Extension with Ring of 0.8 , with a difference in final diameter (Df) less than or equal to $5 \mathrm{~cm}$ with the Df of the Slump test.

An aspect that should not be forgotten for the selection of the SCC-MR in addition to the properties expected in fresh and hardened state such as cost placement application and durability conditions among others, it is the engineer's criterion which is decisive to accept or reject it. The fresh appearance of a SCC and a SCC-MR is the same, for the same design criteria. The SCCs-RM, were used for structural applications; specifically, in beams and columns in the same laboratory and in the manufacture of prefabricated buildings (Expo-Camacol-Medellín), as a proposal for urban furniture in Colombia [7].

According to the dosage proposal of De La Cruz [1] for SCCs-RM; described below and in order, the protocol to follow to obtain this type of concrete, without the use of additions or viscosity modifying agents (AMVs) in the LABEST.

\section{A. Mortar phase}

In the design of the SCC-RM it is essential to define the Mortar Phase (cement, water, sand and additive), since it will not only determine the compatibility between the sp and the cement paste, but also the optimum quantity of sp to maintain the conditions of autocompactabilidad in the concrete, without increasing indiscriminadamente the costs. This phase is determined by the Marsh Cone or Fluidity test standardized by ASTM 939 [1], [3], [7], [8], which allows to determine the fluidity in conjunction with the Mini Slump test, which determines the consistency of the mixture. Initially, the resistance and water / cement ratio (W / C) must be defined, with values below 0.6. In order to ensure that fluency will not depend on high $\mathrm{W} / \mathrm{C}$ ratios.

1) Resistance and A / C Ratio.

The mechanical strength of the concrete must be below $45 \mathrm{MPa}$ (medium-low resistance in Colombia). It is part of the precedent that in a hardened state, it does not matter if it is self-compacting or not in comparison with an $\mathrm{HC}$ of the same mechanical strength. To define the $\mathrm{W} / \mathrm{C}$ relationship we start from the Equation of Abrams Eq. (1) [5], since this equation shows the dependence that exists between the resistance and the $\mathrm{A} / \mathrm{C}$ as show in (1).

$$
f^{\prime}{ }_{c r}(M P a)=\frac{K_{1}}{K_{2}{ }^{W / C}}
$$

Where: W/C: Water/Cement ratio

$\mathbf{K}_{\mathbf{1}}, \mathbf{K}_{\mathbf{2}}$ : These are factors that depend on the compressive strength of the cement used (NTC220) [6] and are necessary to obtain the W / C ratio.

Clearing the $\mathrm{w} / \mathrm{c}$ relation of Eq. (1), Eq. (2) is obtained.

$W / C=\frac{K_{1}}{f^{\prime} c^{\prime} * \ln K_{2}} \quad$ The values of $\mathrm{K} 1$ and $\mathrm{K} 2$ used

are those showing in Table II.

TABLE II

VALUES FOR K1 AND K2 ACCORDING TO THE STRENGTH OF THE CEMENT [7].

\begin{tabular}{|c|c|c|c|}
\hline $\begin{array}{l}\text { Cement } \\
(\mathrm{MPa})\end{array}$ & Strength & $K_{l}$ & $K_{2}$ \\
\hline$<20$ & & 75.00 & 14.50 \\
\hline $25-30$ & & 90.00 & 13.00 \\
\hline
\end{tabular}

\begin{tabular}{ccc}
$30-35$ & 110.00 & 12.50 \\
$35-40$ & 130.00 & 11.00 \\
$>40$ & 145.00 & 10.50 \\
\hline
\end{tabular}

2) Definition of mortar

All the mortars were prepared in a mechanical mixer (Fig. 1), with two (2) speeds taking into account the times shown in Table III.

TABLE III

MORTAR TIME AND SPEEDS IN THE MIXER.

\begin{tabular}{ccc}
\hline \hline Time $(s)$ & Components & Speed \\
\hline 30 & Fine and cement & Slow \\
60 & $90 \%$ of the water & Slow \\
60 & Stop and scrape & 0 \\
30 & Rest of the water & Slow \\
150 & Mortar & Quick \\
\hline \hline
\end{tabular}

The cement content of 1000g was kept constant, for a W / C $=0.5$. The solids percentage of the sps additives was taken into account for the calculation of the mixing water [1].

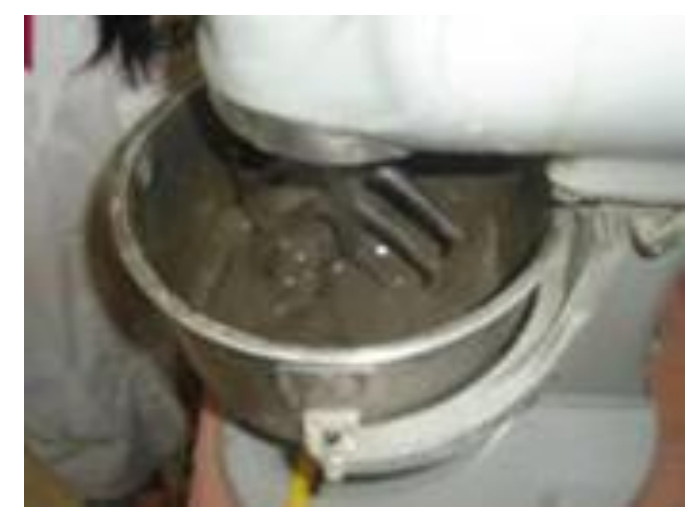

Fig. 1. Two (2) speed mechanical mixer [7]

\section{3) Test with the Marsh Cone}

As already pointed out, the mortar has a decisive influence on the consistency and fluidity of fresh concrete as well as on the mechanical and durability properties of hardened concrete. Its optimization is a priority for the design of the SCC-RM, following a quick and simple procedure to evaluate the characteristics of each type of mortar (water + cement + additives) and which is based on the measurement of the time of flow through the Cone of Marsh. There is a point, from which, the increase in the dose of sp does not cause a significant increase in fluidity; so this point is defined as the "Saturation point" of the mortar [8].

The Marsh Cone test [7] is a simple test that determines the flow time of the mortar (See Fig. 2.).

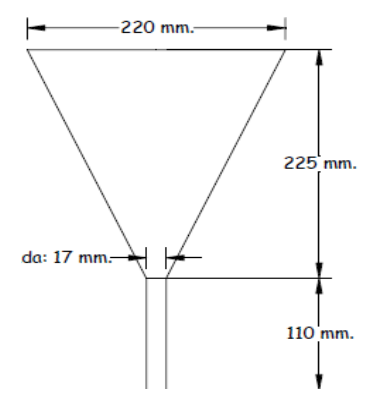




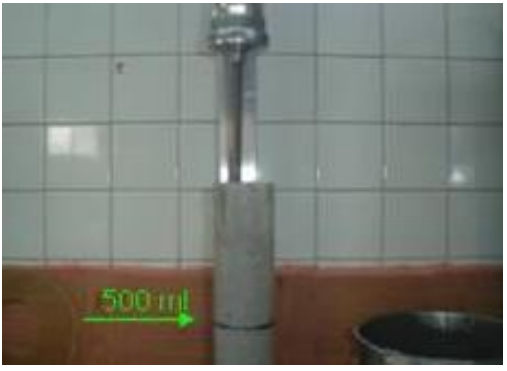

Fig. 2. Marsh Cone and Time in the Marsh Cone [7]

\section{4) Quantitative determination of the saturation point}

By varying the contents of $\mathrm{sp}$ in the mortar, different times are obtained and as the time decreases the fluidity increases. With this test and different percentages of additive you can determine the saturation point which according to the Log curve (time [s]) vs. sp / c, allow an angle of $140 \pm 10^{\circ}$ as suggested by Gomes (2002) [9] and De La Cruz (2006) [1] (Fig. 3.).

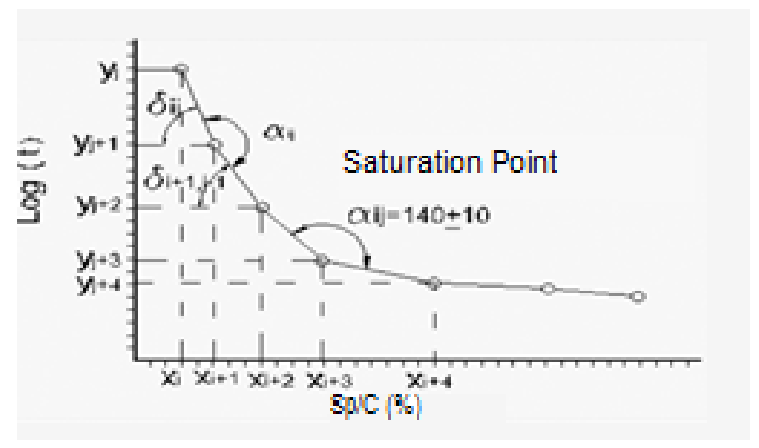

Fig. 3. Graph of the saturation point [9]

According to Fig. 3, the inclinations $\delta$ and $\alpha$ respectively are determined and the point that complies with an angle $\alpha$ within the range $140^{\circ} \pm 10^{\circ}$ is selected indicating the "Saturation point" [9].

\section{5) Test in the Mini Slump}

It allows determining the consistency of the mortar and can also be observed under visual evaluation if segregation and / or exudation occurs (Fig. 4). It can also be associated with placement and consolidation without vibration [1].

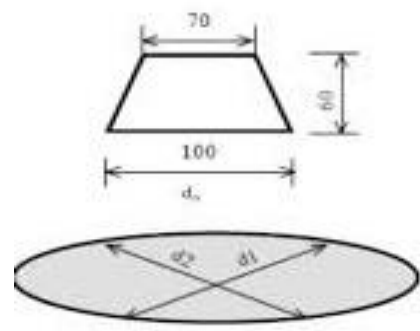

Fig. 4. Mini Slump [7]
In this test the final diameter is determined, as shown in Fig. 5, after demolding. The diameter should be between $280 \pm 20 \mathrm{~mm}[1],[2]$.

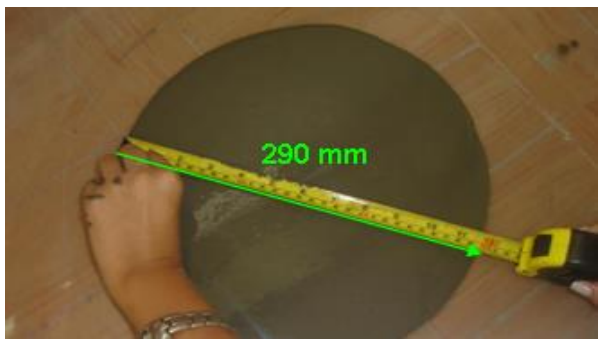

Fig. 5. Final Diameter Mini Slump (Mortar) [7]

6) Taking data in the LABEST

The tables and figures corresponding to the definition of saturation points are presented with three (3) types of sps additives with different percentages of solids available in the city of Medellín. All the data and graphs were obtained following the methodology described in this article. In Table IV and Fig. 6 the results obtained with the Marsh Cone and the diameters can be observed with the Mini Slump with sp additive and $36 \%$ solids content [7].

TABLE IV

OPTIMIZATION OF THE SP WITH $36 \%$ SOLIDS.

\begin{tabular}{ccccccc}
\hline \hline $\begin{array}{c}\text { Additive } \\
(\%)\end{array}$ & $\begin{array}{c}\text { Solid } \\
s p\end{array}$ & $\begin{array}{c}\text { Liquid } \\
(\mathrm{g})\end{array}$ & $\begin{array}{c}\text { Water }(\mathrm{g}) \\
(\mathrm{g})\end{array}$ & $\begin{array}{c}T \\
\text { Marsh } \\
(\mathrm{s})\end{array}$ & $\begin{array}{c}T \\
\text { Marsh } \\
(\text { Log })\end{array}$ & $\begin{array}{c}\text { Diameter } \\
(\mathrm{mm})\end{array}$ \\
\hline 0.045 & 1.30 & 0.85 & 399.20 & 7.39 & 0.87 & 290 \\
0.050 & 1.40 & 0.90 & 399.10 & 7.06 & 0.85 & 315 \\
0.060 & 1.70 & 1.10 & 398.90 & 6.95 & 0.84 & 393 \\
0.075 & 2,10 & 1.35 & 398.70 & 6.73 & 0.83 & 396 \\
0.085 & 2,40 & 1.55 & 398.50 & 5.92 & 0.77 & 420 \\
\hline \hline
\end{tabular}

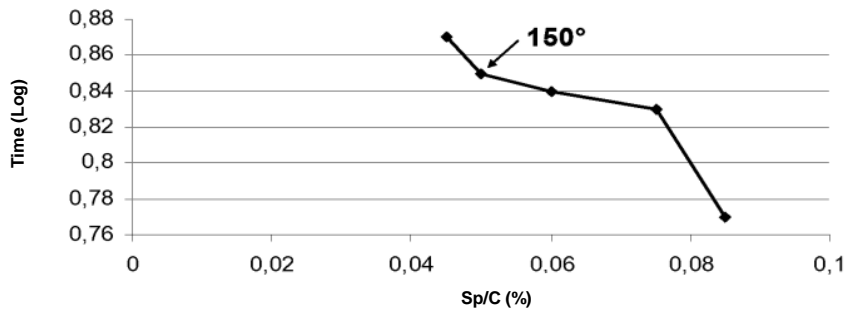

Fig. 6. Saturation Point (sp 36\% solids)

In Table $\mathrm{V}$ and Fig. 7 you can see the results obtained with the Marsh Cone and the diameters with the Mini Slump, with sp additive and $32 \%$ solids content [7].

TABLE V OPTIMIZATION OF THE SP WITH 32\% SOLIDS

\begin{tabular}{ccccccc}
\hline \hline $\begin{array}{c}\text { Additive } \\
(\%)\end{array}$ & $\begin{array}{c}\text { Solid } \\
s p \\
(g)\end{array}$ & $\begin{array}{c}\text { Liquid } \\
s p(g)\end{array}$ & $\begin{array}{c}\text { Water } \\
(\mathrm{g})\end{array}$ & $\begin{array}{c}\text { Tarsh } \\
(\mathrm{s})\end{array}$ & $\begin{array}{c}T \\
\text { Marsh } \\
(\text { Log })\end{array}$ & $\begin{array}{c}\text { Diameter } \\
(\mathrm{mm})\end{array}$ \\
\hline 0.050 & 1.60 & 1.10 & 398.90 & 11.71 & 1.07 & 190 \\
0.060 & 1.90 & 1.30 & 398.70 & 10.70 & 1.03 & 205 \\
0.070 & 2.50 & 1.70 & 398.30 & 9.07 & 0.96 & 265 \\
0.095 & 3.00 & 2.05 & 398.00 & 8.82 & 0.95 & 240 \\
0.100 & 3.10 & 2.10 & 397.90 & 8.48 & 0.93 & 235 \\
\hline \hline
\end{tabular}




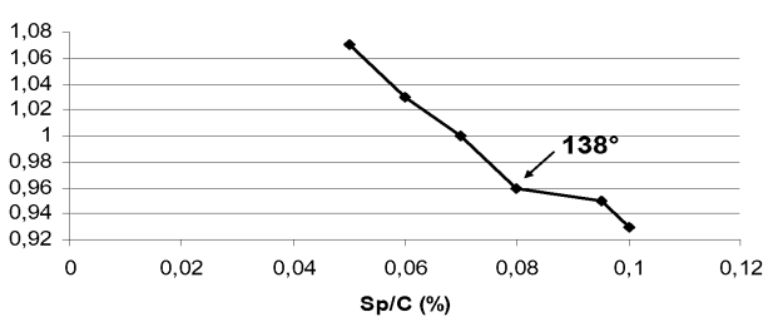

Fig. 7. Saturation Point (sp 32\% solids)

In Table VI and Fig. 8. the results obtained with the Marsh Cone, the diameters with the Mini Slump and the angle of $146^{\circ}$ respectively can be observed, using the sp additive with $28 \%$ solids [7].

TABLE VI

OPTIMIZATION OF THE SP WITH 28\% SOLIDS.

\begin{tabular}{ccccccc}
\hline \hline $\begin{array}{c}\text { Additive } \\
(\%)\end{array}$ & $\begin{array}{c}\text { Solid } \\
s p \\
(g)\end{array}$ & $\begin{array}{c}\text { Liquid } \\
s p(g)\end{array}$ & $\begin{array}{c}\text { Water }(g) \\
(\mathrm{g})\end{array}$ & $\begin{array}{c}\text { Time } \\
\text { Marsh } \\
(\mathrm{s})\end{array}$ & $\begin{array}{c}\text { Marsh }) \\
(\text { Log })\end{array}$ & $\begin{array}{c}\text { Diameter } \\
(\mathrm{mm})\end{array}$ \\
\hline 0,60 & 2.14 & 1.54 & 398.46 & 10.70 & 1.03 & 250 \\
0,07 & 2.50 & 1.80 & 398.20 & 10.10 & 1.00 & 260 \\
0,08 & 2.86 & 2.06 & 397.94 & 9.10 & 0.96 & 270 \\
0,09 & 3.21 & 2.31 & 397.69 & 8.90 & 0.95 & 280 \\
0,10 & 3.39 & 2.44 & 397.56 & 9.10 & 0.96 & 280 \\
\hline \hline
\end{tabular}

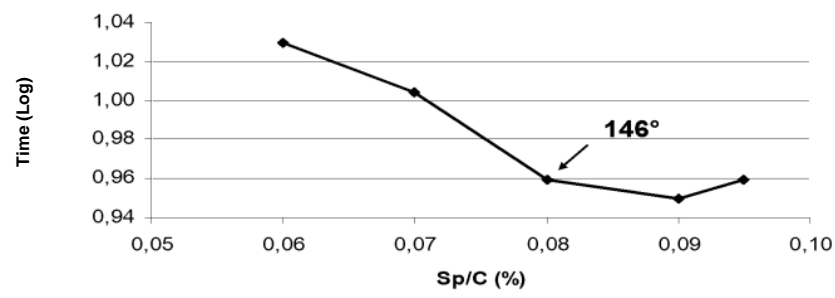

Fig. 8. Saturation Point (sp 28\% solids)

It was decided to design mixtures of SCC-RM with the sp additive with $28 \%$ solids content. The mortar had a better consistency due to a better compatibility between it and the cementing material (Fig. 6). It is essential to optimize the Granular Skeleton as proposed by De La Cruz (2006) [1], [3], [7], [8]. The procedure methodology to obtain the SCC-RM [1] is described below.

\section{B. Granular skeleton}

\section{1) Grading stabilization}

The stability of a granular skeleton containing fine and coarse material depends on the distribution of the different sizes of its particles the shape of these their volumetric weight, their internal friction and their cohesion. The resistance of a concrete is the most important property and one of the factors that most influences it is the granulometric distribution of the particles, without neglecting the shape and texture.

The strength of a concrete is influenced by the proportion of coarse and fine aggregates that the granular skeleton contains. In Table VII the three physical states of a granular skeleton and some of its physical properties are presented [8].
TABLE VII

CHARACTERISTICS OF THE GRANULAR SKELETON.

Characteristics
Aggregates without fines. Contact grain to grain.
Variable volumetric weight its compaction is difficult.
Aggregates with sufficient fines for a high density.
Grain to grain contact increased resistance, greater
volumetric weight. Moderately difficult to compact.
This state decreases its volumetric weight.
Aggregates with a large amount of fines. There is no
grain-to-grain contact being within a matrix of fines.
Its compaction is not difficult.

As seen in Table VII, a granulometry that contains few or no fines and that has good size distribution obtains its stability thanks to a direct contact between the particles, however this material presents problems of workability due to its non-cohesive nature. A grind that contains a sufficient amount of fines to fill all the voids between the particles facilitates a direct contact between them. The presence of the fines will cause a better distribution of the efforts compared to the granular skeleton without fines.

A material with a large amount of fines, no stresses are transmitted through the contacts between the coarse particles, once they will float in the finest aggregates and, consequently, the general behavior of the concrete will be consistent with that of the thin particles by increasing the content of fines. Taking the basic dose as a reference, the volumetric weight increases, while the granular skeleton is thicker.

By increasing fine content, the optimum conditions are correct. Increase in the fine content will cause a substantial decrease in the volumetric weight [10]. With the precedence of a granulometry which has no discontinuities and with equidimensional aggregates Fuller proposes (1), [8]:

$\mathrm{P}=100 *$ (d) $\wedge \mathrm{n} /$ (D) $\wedge$ n

(1)

Where:

P: percentage by weight of a certain size $d$

d: a certain particle size

D: maximum size of the skeleton to be evaluated

$\mathrm{n}$ : exponent that depends on the shape of the granulometric curve

It has been seen that when $\mathrm{n}$ has a value of 0.5 it has the best distribution of sizes and therefore the maximum volumetric weight. If the maximum size of the particles is $3 / 4$ ", then according to Fuller's equation, it would have to be $6.2 \%$ by the No. 200 mesh. However because in practice the aggregates do not fit with a perfect distribution of sizes but have the tendency to form gaps, it is necessary to adjust the granulometry [10] [11] [12] [13]. Said adjustments consist of increasing the content of fines in the granular skeleton, to obtain the maximum volumetric weight.

\section{2) Optimization of the granular skeleton}

The determination of the granular skeleton turns out to be the most important phase in the dosing process of the SCC-RM, since its objective is to minimize the 
relation of voids between the materials to be used. For the optimization of the granular skeleton, the

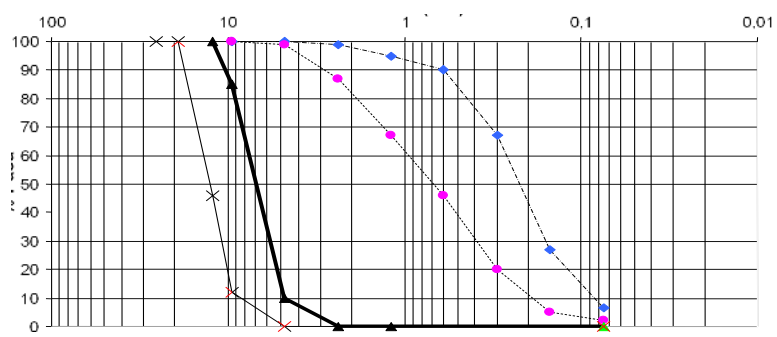

granulometry of the materials used was adjusted to the maximum density theoretical curve of Fuller [14] [15] [16] [17] [18] (Fig. 9).

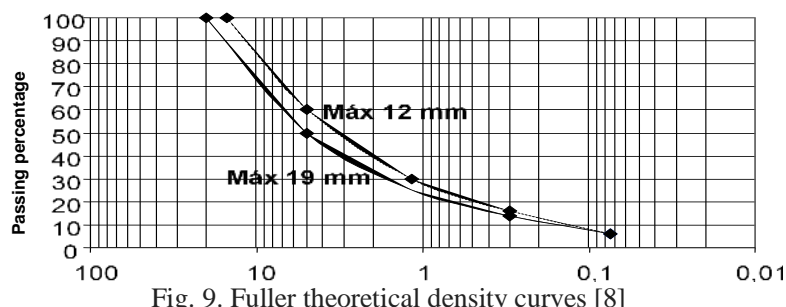

The maximum compactness test [1], [8] as shown in Fig. 10.

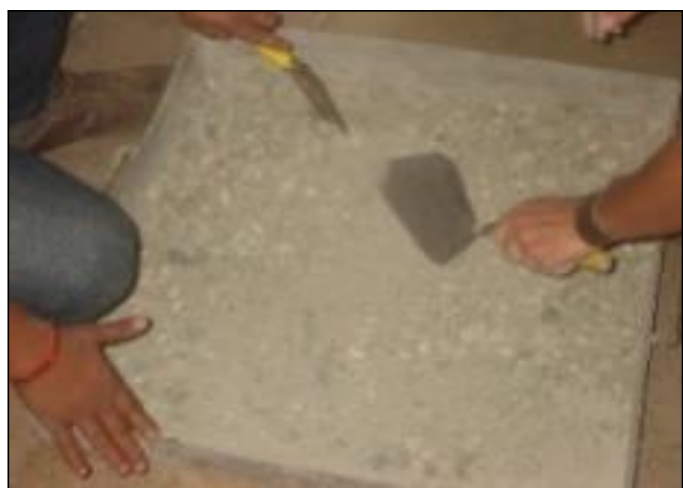

Fig. 10. Mixture of materials for Maximum Compactness test [1] [10].

The aggregates used in this work were those available in the quarries of the city of Medellín whose physical characteristics meet the Colombian specifications [6]. They were defined for work purposes as fine-medium aggregate (sand of $2 \mathrm{~mm}$ to $5 \mathrm{~mm}$ ) and as coarse aggregate, in two (2) proportions coarse aggregate of maximum size $3 / 8$ "(5 $\mathrm{mm}$ to $12 \mathrm{~mm})$ and coarse aggregate of maximum size $3 / 4$ " (12 $\mathrm{mm}$ to $19 \mathrm{~mm}$ ). The appearance of the materials can be seen in Fig. 11.

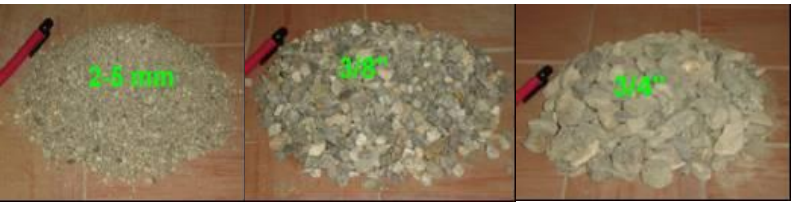

Fig.11. Aggregates of Medellin

In Table VIII, the results of the physical tests necessary to dose the SCC-RM in the LABEST are presented.
TABLE VIII

PHYSICAL TESTS OF THE AGGREGATES.

\begin{tabular}{|c|c|c|c|}
\hline \multirow[t]{2}{*}{ Property } & Sand $(2-5 \mathrm{~mm})$ & Arid 3/8" & Arid 3/4"' \\
\hline & \multicolumn{2}{|c|}{$0 \mathrm{~mm}-5 \mathrm{~mm}$} & \\
\hline $18 \mathrm{~mm}-20 \mathrm{~mm}$ & \multicolumn{2}{|c|}{$5 \mathrm{~mm}-12 \mathrm{~mm}$} & \\
\hline SSS Density $\left(\mathrm{g} / \mathrm{cm}^{3}\right)$ & 2.67 & 2.65 & 2.72 \\
\hline Dry density $\left(\mathrm{g} / \mathrm{cm}^{3}\right)$ & 2.62 & 2.63 & 2.66 \\
\hline Absorption Percentage & 1.70 & 1.01 & 2.00 \\
\hline
\end{tabular}

In Fig. 12, the granulometric curves of the aggregates used are presented. The percentages of the coarse aggregate of $3 / 4$ "as maximum size and with the fines of Number 4 as the nominal size used for this test are presented in Table IX.

Fig. 12. Granulometric Curve of 4 quarry materials [1] [3] [4] [10] [23] [24]

Fig. 12. Granulometric Curve of 4 quarry mat
TABLE IX

PERCENTAGES OF MEDIUM AND COARSE AGGREGATES

\begin{tabular}{ccc}
\hline \hline$\%$ Fine $(5 \mathrm{~mm})$ & $\%$ Thick $(19 \mathrm{~mm})$ & $\%$ Vv (Ratio of voids) \\
\hline 0 & 100 & - \\
10 & 90 & 40.8 \\
20 & 80 & 34.8 \\
25 & 75 & 37.8 \\
30 & 70 & 37.1 \\
35 & 65 & 36.6 \\
40 & 60 & 35.3 \\
45 & 55 & 36.3 \\
50 & 50 & 34.9 \\
55 & 45 & 34.2 \\
60 & 40 & 34.2 \\
65 & 35 & 35.6 \\
70 & 30 & 34.6 \\
\hline \hline
\end{tabular}

With the percentages of the aggregates of Table IX it was possible to minimize the volume of voids up to $34 \%$ as shown in Fig. 13. Despite being a relatively good value implies high contents of cement in the design mortar phase and in the paste volume of the final mixture. Based on the above it was decided to perform the granulometric analysis for this point of maximum compactness [1], [7], [8] and it was superimposed with the maximum density theoretical curve of Fuller where it was observed (Fig. 14), that the material available had a low content of fines.

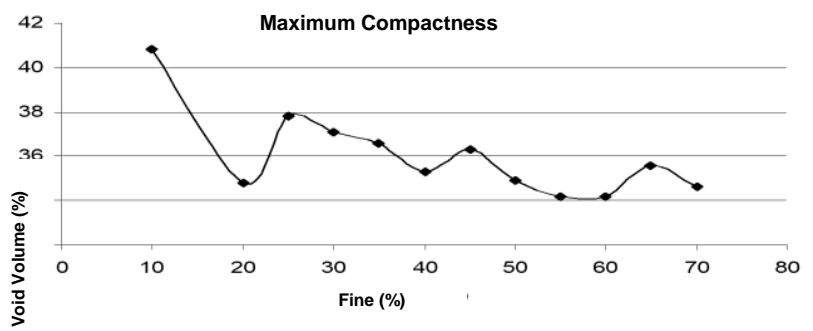

Fig. 13. Maximum Compactness with two (2) materials. 
Fig.14. Fuller's Theoretical Curve Overlay and Experimental Curve (two (2) materials)

To obtain a vacuum ratio that would allow obtaining a SCC-RM with the minimum volume of voids it was decided to perform an ideal curve and in this way save costs in the final mixture. The idealization of this curve was made in Size $(\mathrm{mm})$ the LABEST obtaining a void ratio of $28 \%$. It is worth noting that the previous development (optimizing the granular skeleton to the maximum) in search of the lowest content of voids it is possible, in the laboratory. Sieving conditions can be generated and the aggregates mixed in a controlled manner, situation that becomes more complex industrially or in quarry.

Based on the foregoing, it is not possible to commercially obtain a curve that exactly matches the characteristics of Fuller's theoretical curve; but if with a certain approach.

Once the previous study was done it was decided to carry out the maximum compactness test with another finer material $(0 \mathrm{~mm}$ to $2 \mathrm{~mm}$, obtained from the sieving in the LABEST), with the percentages of each granular material available and presented in Table $\mathrm{X}$ and that for work purposes they have been discriminated as Fine, Medium and Thick.

TABLE $X$

PERCENTAGES OF FINE, MEDIUM AND COARSE AGGREGATE.

\begin{tabular}{llll}
\hline \hline \% Fine & $\begin{array}{c}\% \\
\text { Medium }\end{array}$ & \% Thick & $\% V v$ \\
\hline 5 & 52.3 & 42.8 & 30.9 \\
10 & 49.5 & 40.5 & 30.4 \\
15 & 46.8 & 38.5 & 31.0 \\
20 & 44.0 & 36.0 & 29.3 \\
25 & 41.3 & 33.8 & 30.1 \\
30 & 38.5 & 31.5 & 29.9 \\
35 & 35.8 & 29.3 & 30.5 \\
40 & 33.0 & 27.0 & 32.2 \\
\hline \hline
\end{tabular}

Finally, with this combination, the void ratio was optimized, reaching 29.3\% of voids, as shown in Fig. 15.
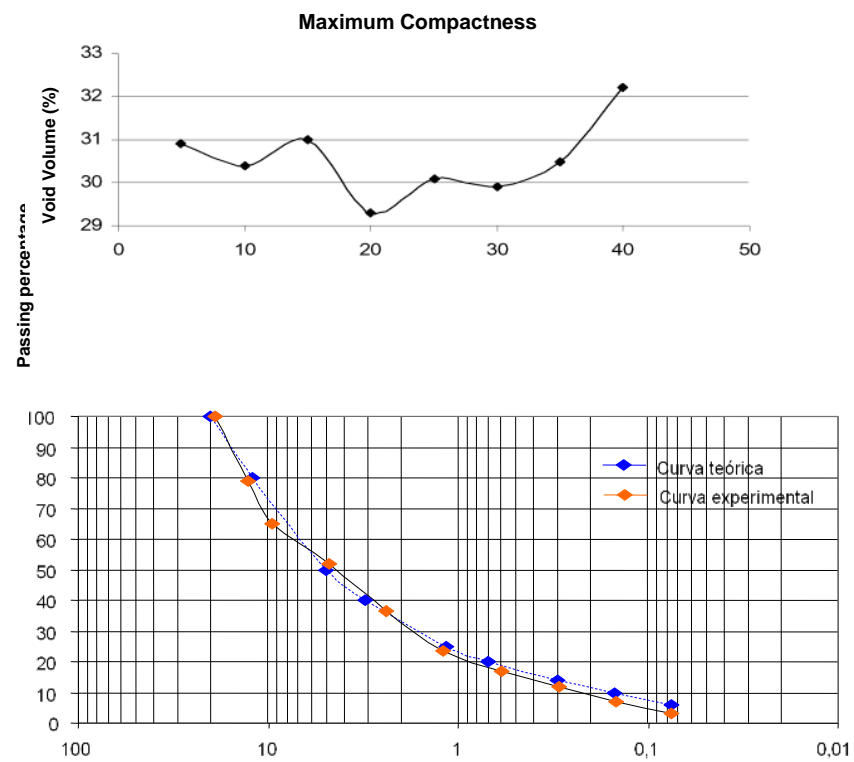

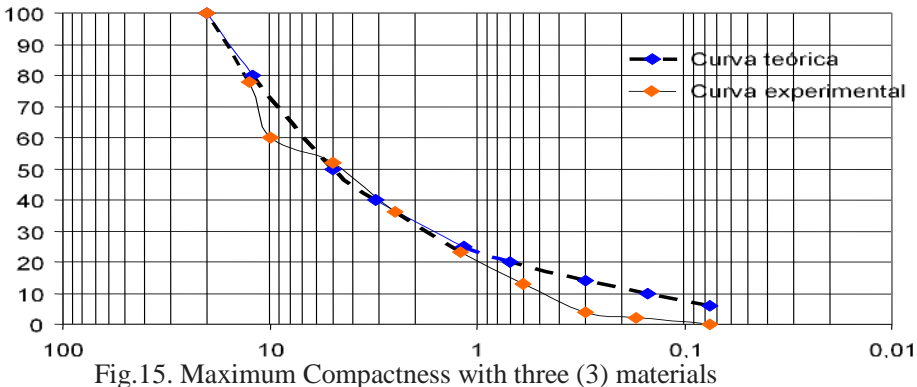

It was also decided to compare with the Theoretical Curve of Fuller and its behavior is presented in the following Fig. 16. The final result presents a curve quite adjusted to the heoretical one.

Fig.16. Fuller's Theoretical Curve Overlay and Experimental Curve (three materials)

\section{DOSING OF SCC-RM WITH CEMENT TYPE I IN COLOMBIA}

Table XI shows three of the best SCC-RM test dosages with Portland Cement Type I [7] [9] [31] [32] [33].

The dosage three, was used in the manufacture of beams, columns and prefabricated in the LABEST at the level of teaching practices and participation in events in the city of Medellin (TECNOVA and Expo-Camacol, 2008) [7] [34] [35] [36] [37] [38].

TABLA XI

MIXTURES AND RESULTS OF THE SCC.RM CONCRETE, IN THE LABEST [39] [40].

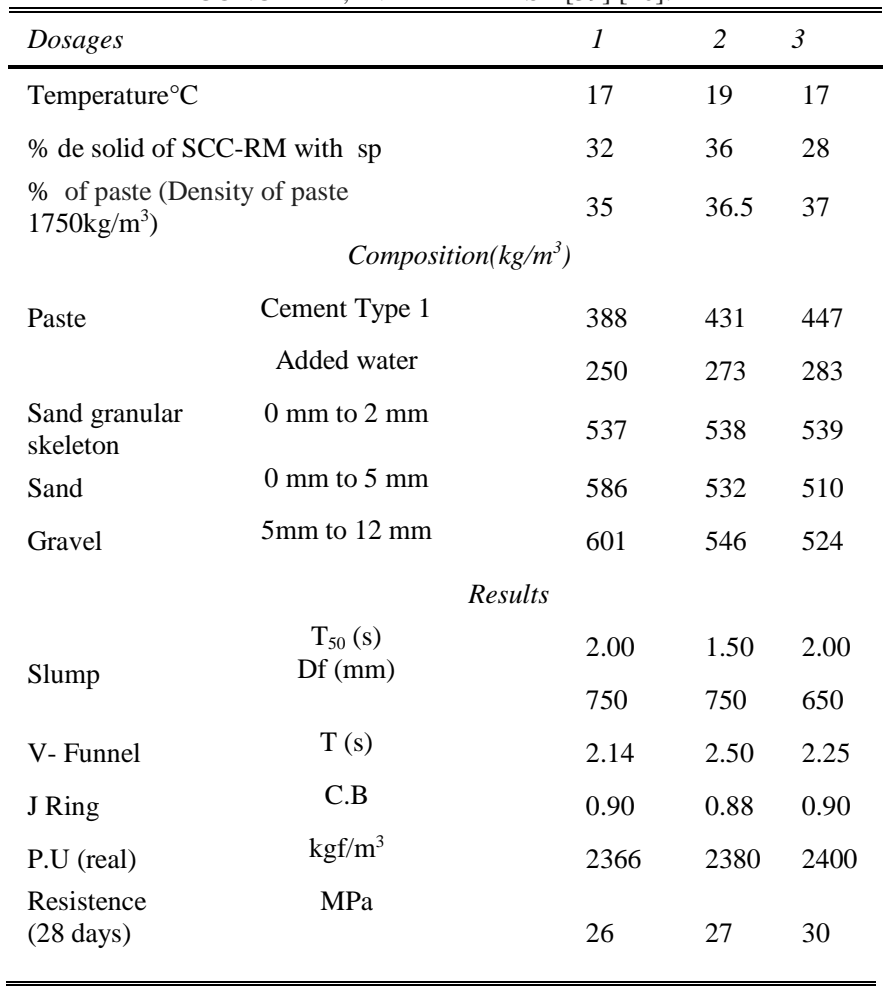

Results of resistance, average of three cylinders with neoprene.

\section{Conclusions}


- It was proved that the methodology proposed by De La Cruz (2006) [1], is easy to apply and allows obtaining results in accordance with the regulations established in Colombia and meets the expectations of safety, functionality and economy.

- The infrastructure adopted by LABEST offers an effective and forceful tool for teaching practices and Extension and Research services for the implementation of SCCs-RM in Colombia.

- The characterization of the materials used for the dosing of the SCCs-RM [1] defines the applicability of the same in an efficient way.

- The applicability of SCCs-RM in Medellín Colombia It set a precedent for the topicality of highly competitive concretes in the country.

- The appropriation and application of the methodology proposed by De La Cruz (2006) [1] for the manufacture of SCCs-RM offers an efficient, updated, efficient and cuttingedge alternative in academic and professional training spaces already implemented in other countries.

- It was verified in the applications that the execution times and costs of a cubic meter of SCC-RM put into work have a reduction of up to $40 \%$ and $16 \%$ respectively.

\section{REFERENCES}

[1] C.J. De La Cruz, "HORMIGÓN AUTOCOMPACTABLE DE RESISTENCIA MEDIA (SCC-RM)", PATENTE DE INVENCIÓN Nº9396-2018, septiembre, 20, 2018.C.J. De La Cruz, "Hormigones Autocompactables de Resistencia Media para Aplicaciones Estructurales," Tesis Doctoral, Universitat Politècnica de Catalunya, Barcelona, España, 2006.

[2] C.J. De La Cruz et al., "Ensayos a Cortante de Vigas de Hormigón Estructural," DYNA, vol. 159, pp. 36-41, Septiembre, 2009.

[3] C.J. De La Cruz et al., "Evaluación de la Retracción y la Fluencia en el Hormigón Autocompactable de Resistencia Media," DYNA, vol. 175, pp. 120-127, septiembre, 2012.

[4] J. Ortíz, "Estudio experimental sobre la influencia de la temperatura ambiental en la resistencia del hormigón preparado," Tesis Doctoral, Universitat Politècnica de Catalunya, Barcelona, España, 2005.

[5] O. Giraldo. Guía Práctica para el Diseño de Mezclas de Hormigón. Medellín: Universidad Nacional de Colombia, 1988.

[6] Normas Técnicas Colombianas para la Construcción. Bogotá: ICONTEC. 1984.

[7] C.J. De La Cruz. Desarrollo de HAC-RMs, en Colombia. Medellín: Universidad Nacional de Colombia, 2009.

[8] L. Herrera y N. Úsuga, "Caracterización de Hormigones Autocompactables en Colombia. Medellín: Universidad Nacional de Colombia, 2009.

[9] P. Gomes, "Optimization and Characterization of High-Strength Self-Compacting Concrete," Tesis Doctoral, Universitat Politècnica de Catalunya, Barcelona, España, 2002.

[10] J. Ortiz, "Análisis Granulométricos a los Áridos", Barcelona, España, 2005.

[11] ACI, Building Code Requirements for Reinforced Concrete. Detroit: American Concreter Institute, Detroit 1977.

[12] ACI, Committee 363 State of the Art Repor High-Streng Concrete. Journal 8181 (4), pp. 364-411, 2010.

[13] AENOR, "ENSAYOS DE HORMIGON Y MORTERO," vol. 10, Recopilación de Normas UNE, Madrid, España, 1998.

[14] AFGC, "Betons Auto-Plaçants: Recommandations Provisoires", Association Française de Génie Civil, 63 p., 2000.

[15] G. Agranati, "estudio sobre la aplicabilidad de los modelos de cálculo de la fluencia y retracción de SCC,". Tesis Doctoral, Universidad Politécnica de Madrid, Madrd, España, 2008.

[16] P. Aïtcin, "Demystifying Autogenous Shrinkage". Concrete International, vol. $21 \mathrm{~N}^{\mathrm{o}} 11$, pp. 107-131, July, 1999.
[17] J. Ambroise and J. Péra, "Properties of Self-Leveling Concrete: Influence of a Viscosity Agent and Cement Content," Proc. Fifth International CANMET/ACI Conference on Recent Advances in Concrete Technology, ACI SP 200, Ed. V. M. Malhotra, American Concrete Institute, EE.UU., pp. 367-380, 2001.

[18] ASCE., Usos del hormigón autocompactable en Japón, Europa y los Estados Unidos. Tecnología del Puente. U.S Department of transportation FEDERAL HIGHWAY of TRANSPORTATION FHWA. American Society of Civil Engineers, 2005. www.fhwa.dot.gov/bridge/scc.htm

[19] J. Assad and K. H. Khayat, "Assessment of thixotropy of selfcompacting Concrete-and Concrete-equivalent-Mortar-Effect of Binder Composition and content," CEMENT and CONCRETE RESEARCH, Vol. 34, № 11, 2004.

[20] ASTM Designation: C 300-91 "Standard Practice for Mechanical Mixing of Hydraulic Cement Pastes and Mortars of Plastic Consistency," 1991.

[21] ASTM Designation: C 512 - 87, "Standard Test Method for Creep of Concrete in Compression" (Reapproved 1994).

[22] ASTM C1621 M-08, "Standard Test Method for Passing Ability of Self-Consolidating Concrete by J-Ring," 2008.

[23] ASTM C1611-05, "Standard Test Method for Slump Flow of Self Consolidating Concrete, 2005.

[24] P.J.M. Bartos and M. Grauers, "Self-Compacting Concrete. Concrete," Vol. 33, No 4, pp. 9-13, 1999.

[25] P.J.M. Bartos, "Key Properties of Fresh Self-compacting Concrete: A Case for Standardisation," Proc. Seminar on Self-Compacting Concrete, Malmö, Copenhagen, pp. 21-26, 2000.

[26] P. J.M. Bartos, "Measurement of key properties of self-compacting concrete, CEN/STAR PNR Workshop, 6 p, 2000.

[27] B. Barragán, "Hormigón autocompactable de alta resistencia para el refuerzo de túneles". III congreso de ache de puentes y estructuras. las estructuras del siglo XXI, Sostenibilidad, Innovación y retos del futuro. Investigaciones y estudios, Madrid, España, pp. 599-611, 2005.

[28] D. Beaupré, P. Lacombe, and K.H. Khayat, "Properties and Scaling Resistance of Air Entrained Self-Consolidating Concrete," Laboratory Investigation of Rheological Mater. Struct., Vol. 32, pp. 235-240, 1999.

[29] P. Billberg, "Self-Compacting Concrete for Civil Engineering Structures - The Swedish Experience," CBI Report, Swedish Cement and Concrete Research Institute, Estocolmo, Suecia, 80 p, 1999.

[30] P. Borralleras, "Obras y realizaciones con hormigones autocompactables," Jornada Técnica sobre Hormigón Autocompactable: Un Hormigón para el Siglo XXI, Documentación Técnica, IECA Levante, Valencia, pp. 55-70, 2003.

[31] P. Borralleras, "Hormigón autocompactable para aplicaciones convencionales" iii congreso de ache de puentes y estructuras. las estructuras del siglo XXI," Sostenibilidad, Innovación y retos del futuro. Investigaciones y estudios. Vol. 1. pp. 469-481, 2005.

[32] W. Brameshuber and S. Uebachs, "Self-Compacting Concrete Application in Germany," Proc. 6th International Symposium on Utilization of High Strength / High Performance Concrete, Eds. G.König, F.Dehn y T.Faust, Leipzig University, Alemania, Vol. 2, pp. 1503-1514, 2002.

[33] M. Bravo, "Caracterización y Utilización del Hormigón Autocompactable". Projecte o Tesina d'Especialitat. Enginyerie de la Construcció. Escola Tècnica Superior d’Enginyers de Camins, Canals I Ports de Barcelona, España, 2004.

[34] H.J.H. Brouwers and H.J. Radix, "Self-Compacting Concrete: Theoretical and experimental study," Cement and Concrete Research 35. Received 11 August 2004, pp. 2116-2136, accepted june 2005 .

[35] M.A. Bury and E. Bühler, "Methods and Techniques for Placing Self-Consolidating Concrete," - An Overview of Field Experiences in North American Applications. Proc. First North American Conf. on the Design and Use of Self-Consolidating Concrete (Rosemont, Illinois, EE.UU.), Center for Advanced Cement-Based Materials, Evanston, Ill., EE.UU, 7. p., 2002.

[36] V. K. Bui, D. Montgomery, I. Hinczak and K. Turner, "Rapid testing method for segregation resistance of self-compacting concrete," Cement and Concrete Research, vol. 32, pp. 1489-1496, 2002. 
[37] Carbonari et al., "Time-dependent mechanical behavior of high performance concretes: Creep and shrinkage", Proc. Intnl. Congress on High-Performance, and Performance and Quality of Concrete Structures, Univ. Federal de Santa Catarina, Florianópolis, Brasil, pp. 39-51. 1996.

[38] CEB, "RILEM/CEB/FIB. Recommendations on reinforcement steel reinforced concrete $\mathrm{RC}-6$ : Bond test for reinforcement steel: 2. Pull-Out Test. Revised edition. 5 p., 1983.

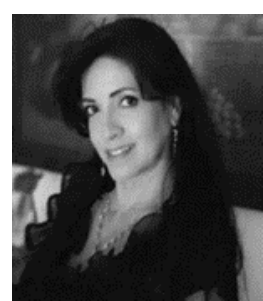

Claudia J. De La Cruz, Civil Engineer, Specialist in Structures, Master in Materials Engineering and Processes of the National University of Colombia Faculty of Mines, $\mathrm{PhD}$ in Engineering Construction Area The Polytechnic University of Catalonia Barcelona-Spain. Tenured Professor in Exclusive Dedication with Tenure of Position. More than 20 articles published in indexed journals. Coordinator of the Structures Laboratory for 11 years, has been a member of the score committee of the National University of Colombia, Director of the Research Group "New trends in materials in Civil Construction", Recognition for outstanding work and teacher promotion Resolution Minutes 29 of 2010. Winner of several calls and regional and national jobs. Patent of Invention (Resolution $\mathrm{N}^{\circ}$ 69396-2018).

ORCID: http://orcid.org/0000-0003-4213-4878 